\title{
Effect of the application of $\beta$-glucans and mannan-oligosaccharides ( $\beta G$ MOS) in an intensive larval rearing system of Paralichthys adspersus (Paralichthydae)
}

\author{
Nicole Piaget ${ }^{1}$, Alonso Vega ${ }^{1,3}$, Alfonso Silva ${ }^{2} \&$ Pedro Toledo $^{2,3}$ \\ ${ }^{1}$ Departamento de Biología Marina, Facultad de Ciencias del Mar \\ Universidad Católica del Norte, Casilla 117, Coquimbo, Chile \\ ${ }^{2}$ Departamento de Acuicultura, Facultad de Ciencias del Mar \\ Universidad Católica del Norte, Casilla 117, Coquimbo, Chile \\ ${ }^{3}$ CEAZA, Centro de Estudios Avanzados de Zonas Áridas, Coquimbo, Chile
}

\begin{abstract}
For successful rearing of the flounder Paralichthys adspersus, it is important to optimize growth and survival in the early larval stages. Several authors indicate that the application of $\beta$-glucans and mannan-oligosaccharides ( $\beta$ G MOS) in rearing water should improve the larval health, diminishing the effects of physiological stress and physical damage that the aquaculture activities cause to the individuals. In order to evaluate the effect of $\beta$ G MOS on $P$. adspersus incorporation on $P$. adspersus larval survival and growth in intensive culture, experiments were carried out with six-days post-hatch larvae, which had only just begun to feed on live prey (rotifers), and fifteen-day post-hatch larvae. Three treatments were used, applying $5 \mathrm{mg} \cdot \mathrm{L}^{-1}, 10 \mathrm{mg} \cdot \mathrm{L}^{-1}$, and $15 \mathrm{mg} \cdot \mathrm{L}^{-1}$ of $\beta \mathrm{G} \mathrm{MOS}$ to the rearing water during the first five days of the experiment and then comparing the results with a control. The results indicate that applications of $5 \mathrm{mg} \cdot \mathrm{L}^{-1}$ of $\beta \mathrm{G}$ MOS in the rearing water enhance larval survival and growth with respect to the control, whereas additions of 15 $\mathrm{mg} \cdot \mathrm{L}^{-1}$ of $\beta \mathrm{G}$ MOS suppressed both of these parameters. This effect increases for larvae that have recently absorbed the yolk sac. An histological analysis of the intestinal epithelium of the larvae suggests that $\beta$ G MOS promotes the expression of monocytes (forerunner cells of macrophages) associated with the non-specific immune system of the fish.
\end{abstract}

Key words: Paralichthys adspersus, flounder, larval rearing, growth rate, survival, $\beta$-glucan and mannan-oligosaccharides, immunestimulants.

\section{Efecto de la aplicación de $\beta$-glucanos y manano-oligosacáridos ( $\beta G$ MOS) en un sistema de cultivo intensivo de larvas de Paralichthys adspersus (Paralichthydae)}

\begin{abstract}
RESUMEN. Para el éxito del cultivo del lenguado Paralichthys adspersus es importante optimizar el crecimiento y la supervivencia en los primeros estadíos de desarrollo larval. Diversos autores señalan que la aplicación de $\beta$-glucanos y manano-oligosacáridos ( $\beta \mathrm{G}$ MOS) en el agua de cultivo debería mejorar la salud de las larvas, disminuyendo los efectos del estrés fisiológico y el daño físico de los individuos causado por las actividades propias de la acuicultura. Con el objetivo de evaluar el efecto de la incorporación del $\beta$ G MOS en la supervivencia y el crecimiento de larvas de $P$. adspersus en cultivos intensivos, se realizaron experimentos utilizando larvas de seis días post-eclosión que recién han comenzado la alimentación con presas vivas (rotíferos) y larvas de quince días post-eclosión. Tres tratamientos aplicando $5 \mathrm{mg} \cdot \mathrm{L}^{-1}, 10$ $\mathrm{mg} \cdot \mathrm{L}^{-1}$ y $15 \mathrm{mg} \cdot \mathrm{L}^{-1}$ de $\beta \mathrm{G}$ MOS al agua de cultivo fueron contrastados durante los primeros cinco días de experimentación con una condición control. Los resultados indican que aplicar $5 \mathrm{mg} \cdot \mathrm{L}^{-1} \mathrm{de} \beta \mathrm{G}$ MOS en el agua de cultivo aumenta la supervivencia y el crecimiento de las larvas con respecto al control, mientras que $15 \mathrm{mg} \cdot \mathrm{L}^{-1} \mathrm{de} \beta \mathrm{G}$ MOS tiene un efecto supresor en ambos parámetros poblacionales. Este efecto aumenta si se aplica en larvas que recién han absorbido el saco vitelino. El análisis histológico del epitelio intestinal de las larvas sugiere que el $\beta \mathrm{G}$ MOS promueve la manifestación de monocitos (células precursoras de macrófagos) asociados al sistema inmune no específico de los peces.
\end{abstract}

Palabras clave: Paralichthys adspersus, lenguado, cultivo larval, tasa de crecimiento, supervivencia, $\beta$-glucanos y manano-oligosacáridos, inmunoestimulante.

Corresponding author: Nicole Piaget (piaget@ucn.cl) 


\section{INTRODUCTION}

Under intensive culture, the manipulation of individuals specimens and the chemical and physical conditions of the system cause physiological stress and physical damage to the fish (Rottmann et al., 1992). Stress during fish larval rearing is intermittent and synergic, which amplifies its negative effect and increases the risk of mortality caused by opportunistic microorganisms or pathogenic agents (Skjermo \& Vadstein, 1999; Ellis, 2001). The application of prophylactic compounds such as $\beta$-glucans and mannan-oligosaccharides ( $\beta \mathrm{G} \mathrm{MOS}$ ) improves the health of fish during the early development stages (pre-larva, larva, post-larva; sensu Silva, 2000), mainly by stimulating the non-specific immune system to create defenses against viral, bacterial, and fungal attacks (Sakai, 1999; Raa, 2000). Moreover, applications of compounds containing $\beta$-glucans $(\beta \mathrm{G})$ are coadjuvant, increasing the fish's resistance to parasites and improving the effectiveness of vaccines (Anderson, 1992; Robertsen et al., 1994). The action of $\beta G$ in the intestine is similar to that of probiotics, stimulating the proliferation of beneficial bacteria that assist the immunological system, permitting decreased the use of exogenous or greater effects from exogenous antibiotics. The mannan-oligosaccharides (MOS), on the other hand, absorb the mycotoxins found in the nutrients commonly used in formulated diets (Vadstein, 1997; Raa, 2000; Bergh et al., 2001; Pryor et al., 2003). Other compounds besides $\beta$ G MOS also activate macrophages, including $\gamma$-interferon, peptides, proteins, and lipopolysaccharides (Sakai, 1999; Raa, 2000; Jin \& Xiao-ling, 2004; Bricknell \& Dalmo, 2005; Kumari \& Sahoo, 2006).

The application of $\beta \mathrm{G}$ for prophylactic purposes in juvenile and adult farmed fish is done through injections (intraperitoneal, pre-anal, or intravenous), or by incorporating these compounds into formulated diets (Robertsen et al., 1994; Sakai, 1999). On the other hand, these compounds can be incorporated through live prey or by applying them directly to the rearing water as immersion baths during the early stages of fish development (Skjermo \& Vadstein, 1999; Bergh et al., 2001; Skjermo \& Bergh, 2004). The compounds that contain $\beta \mathrm{G}$ act at the basal level of the development of the immunological system and are soluble in sea water, facilitating their absorption through the skin, gills, and mouth (Strand \& Dalmo, 1997; Dalmo et al., 2000; Raa, 2000). Nonetheless, although the protocols for administering the prophylactic compounds are effective transfer mecha- nisms to strengthen the immunological system of the fish, the application times for activating and maintaining antibody levels during early development seems to be species-specific (Bricknell \& Dalmo, 2005).

Under larval rearing conditions, the individuals must combat infectious diseases through the nonspecific immune system (Ellis, 2001). This is because the fish larvae have not developed a specific immunological defense system, that is, the capacity to offer immune protection against pathogenic agents (Esteban et al., 1994; Bricknell \& Dalmo, 2005). Thus, a preventive treatment (prophylactic) such as the application of $\beta G$ MOS to the rearing water should increase the survival of the larvae, strengthening the non-specific immune system and, moreover, minimizing the environmental problems associated with other alternative protocol such as vaccines and/ or drug therapy (Anderson, 1992; Raa, 2000). The constant application of such protocols (e.g. vaccines, drugs) over time produces residuals that persist in the environment and are transmitted to other organisms, possibly reaching toxic levels. Furthermore, such protocols favor antibiotic resistance in the pathogens and affect the microbial activity responsible for the breakdown of organic matter in the marine sediments (SERNAPESCA, 2005).

Different techniques have been used to determine whether applied organic compounds improve larval health, most noticeably biochemical analysis, assays with pathogenic bacteria, histological cuts and, recently, immunofluorescence markers. The biochemical analysis are based on blood and/or serum samples (Kumari \& Sahoo, 2006), which are very difficult to obtain from small individual larvae (Bricknell \& Dalmo, 2005). As well, the assays with pathogenic bacteria have shown that the intrinsic factors of the fish (fitness, developmental stage, age) produce greater variability between replicates than between treatments, obscuring the effect of the application of the prophylactic compound (Bricknell \& Dalmo, 2005). Classic histological stains (nuclear, cellular), however, are similar in effectiveness and less costly than immunoflorescent markers for confirming the absorption of these organic compounds in the fish larvae (Cousin et al., 1986; Esteban et al., 1994; Strand \& Dalmo, 1997; Luizi et al., 1999; Ribeiro et al., 1999; Dalmo et al., 2000; Bergh et al., 2001).

In Peru and Chile, the flounder Paralichthys adspersus Steindachner, 1867 is an attractive species for intensive culture (Silva, 2001; Ángeles \& Mendo, 2005). Nevertheless, one of the obstacles for its 
culture, as with most potentially farmed fish species, is its high mortality during the first larval stage. In fact, according to Silva (2000), the first 21 days after eclosion of the egg in P. adspersus rearing are critical; larval mortality nears $80 \%$ during this period. Such mortality rates are frequently reported for larval rearing of other Paralichthys species (Kuronuma \& Fukusho, 1984; Bisbal \& Bengtson, 1995; Silva, 2001; Silva \& Castelló, 2005). Mortality in early and more advanced fish development stages is recurrently associated with diseases produced by infections from opportunistic bacteria and the stress caused by manipulation during culture and the culture system itself (Miranda \& Rojas, 1993; Skjermo \& Vadstein, 1999; Ellis, 2001). For example, in $P$. adspersus, vibriosis is manifested when the fish present stress-related immunedepression (Miranda \& Rojas, 1996). Thus, we propose the hypothesis that the addition of $\beta G$ MOS should decrease mortality in intensive culture of $P$. adspersus larvae. Accordingly, our objective is to evaluate survival and growth in the first larval stage of the farmed flounder given treatments with different concentrations of $\beta \mathrm{G}$ MOS in the rearing water. Furthermore, we documented whether the $\beta G$ MOS compound strengthened the health of the larvae, attempting to detect cells that characterized the non-specific immune system in the intestine.

\section{MATERIALS AND METHODS}

In order to evaluate the effect of $\beta \mathrm{G}$ MOS in the rearing water had on $P$. adspersus larvae, we carried out two experiments in different time periods of the first feeding (live prey) stage. This stage begins when the larvae have absorbed the yolk sac (4-5 days post-hatch) and begin to feed on rotifers (Brachionus plicatilis); it ends between 20 and 25 days post-hatch, when the second stage of feeding (on Artemia) begins (Silva, 2001). In Experiment 1, 6-day post-eclosion larvae were used and, whereas in Experiment 2, 15 -day post-hatch larvae were used. The $\beta$-glucan and mannan-oligosaccharide compound used in the experiments (called DP MOS $\beta$ G) was provided by DESPRO S.A. company (Desarrollo de Proteínas de Chile S.A.). Used as a complement in the diet of farmed fish, this compound is an association of $\beta$-glucans (46\%), mannan-oligosaccharides (53\%), and cytoplasmatic content (1\%). The $\beta \mathrm{G}$ MOS was obtained from yeast (Saccharomyces cerevisiae) through lysis and fractionation of the cell wall, with a particle size that fluctuated between 0.5 and $10 \mu$.

\section{Obtaining the larvae}

The larvae were obtained from two spontaneous spawnings of the $P$. adspersus reproductive stock at the Laboratorio de Peces, Universidad Católica del Norte, in September and October 2002. The fertilized eggs were collected with a $400-\mu \mathrm{m}$ sieve placed in the exterior drain tube of the tanks. The eggs were filtered, washed, and left to rest for approximately 20 $\min$ in a $10-\mathrm{L}$ recipient in order to select the viable eggs according to the protocol described by Silva \& Castelló (2005). The viable eggs, previously quantified and disinfected, were deposited in 100-L tanks and incubated for 54 to $62 \mathrm{~h}$ in filtered, sterilized sea water with ultraviolet light (Silva \& Castelló, 2005). The eclosed larvae were moved to a black, cylindrical-conical 500-L tank with filtered sea water (salinity $34 \pm 0.5$ ), aerated continuously, and kept at room temperature $\left(16-17^{\circ} \mathrm{C}\right)$ until their extraction for the experiments.

\section{Experimental design}

In Experiment 1, larvae of $4.0 \pm 0.3 \mathrm{~mm}$ standard length (six-day post-hatch) were used and, in Experiment 2, larvae of $5.4 \pm 0.2 \mathrm{~mm}$ standard length (15-day post-hatch) were used. Both experiments were carried out during the first stage of feeding of the farmed larvae. In this stage, the larvae are fed with rotifers (Brachionus plicatilis; $5-10$ rotifers $\cdot \mathrm{mL}^{-1}$ ) (Silva \& Vélez, 2005). The rotifers, farmed in batch systems, were fed yeast (Saccharomyces cerevisiae) and enriched with a mixture of microalgae (e.g. Isochrysis sp., Nannochloropsis sp.). Each experiment lasted ten days and, in both cases, the larvae were exposed to treatments with concentrations of 5 $\mathrm{mg} \cdot \mathrm{L}^{-1}, 10 \mathrm{mg} \cdot \mathrm{L}^{-1}$, and $15 \mathrm{mg} \cdot \mathrm{L}^{-1} \beta \mathrm{G}$ MOS through immersion (Tytler \& Blaxter, 1988); a control group was not treated with the compound. This concentration range was previously used in other experiments that evaluated the effect of $\beta G$-based prophylactic compounds on fish larval survival and growth (Dalmo et al., 2000; Bergh et al., 2001; Skjermo \& Bergh, 2004).

The treatments, with three replicates, were distributed at random in 12 black, cylindrical, 30-L tanks at a density of 30 larvae $\cdot \mathrm{L}^{-1}$. The larval groups were treated with $\beta G$ MOS dissolved in sea water at concentrations of $5 \mathrm{mg} \cdot \mathrm{L}^{-1}, 10 \mathrm{mg} \cdot \mathrm{L}^{-1}$, and 15 $\mathrm{mg} \cdot \mathrm{L}^{-1}$, during the first five days of each experiment. The $\beta$ G MOS concentration for each treatment was maintained daily in experimental tank by absorbing the water with a siphon and replacing it with the 
diluted compound in sea water. The sea water used for the $\beta \mathrm{G}$ MOS dilutions was filtered at $1 \mu \mathrm{m}$ and sterilized with ultraviolet light (UV). On days 2 , $4,6,8$, and 10 of the experiments, 30 larvae were extracted from the experimental tanks with a siphon. The sampled larvae were excluded from the survival analyses. After each sampling, the volume of water was decreased proportionally in each tank in order to maintain a constant density (30 larvae $\left.\cdot \mathrm{L}^{-1}\right)$. In both experiments, all the utensils were duly washed and disinfected.

In order to determine the effect of the $\beta \mathrm{G}$ MOS on the larvae, the percentage of survival was evaluated along with the growth rate and the manifestation of monocytes or macrophage precursor cells in the larval intestines. The percentage of survival (S) was calculated for each treatment using the equation $\mathrm{S}$ $=\left(n_{\mathrm{f}} / \mathrm{n}_{\mathrm{i}}\right) \cdot 100\left(\right.$ Downing \& Litvak, 1999), where $\mathrm{n}_{\mathrm{i}}$ and $n_{f}$ are the initial and final number of larvae. The growth specific rate $\left(\mathrm{G}_{\mathrm{s}}\right)$ was calculated for each replicate of each treatment during the experimental period with the equation $\mathrm{G}_{\mathrm{s}}=\left(\left[\ln \omega_{2}-\ln \omega_{1}\right] / \mathrm{T}_{2}-\mathrm{T}_{1}\right)$ $\cdot 100$, where $\omega_{1}$ is the standard length $(\mathrm{mm})$ at time $\mathrm{T}_{1}$ (Downing \& Litvak, 1999). The standard length $(\omega)$ was measured from the extreme anterior point of the upper mandible to the extreme posterior point of the notochord (Downing \& Litvak, 1999) using a profile projector (Nikon V12). All the sampled larvae were preserved in formaline diluted in sea water at $10 \%$ in black plastic bottles with labels for later histological analyses (Muñetón-Gómez et al., 2000; K. Lohrmann, pers. comm.).

The histological cuts of $P$. adspersus larvae were done at the intestinal level since the larvae had not yet developed a functional stomach. In this stage of development, the anterior intestine is responsible for the digestion processes and the posterior intestine for the absorption processes (Ribeiro et al., 1999). The larvae collected for each treatment per sampling time were dehydrated in an increasing battery of ethanol for their later inclusion in paraffin (Muñetón-Gómez et al., 2000). The cuts of the anterior and posterior section of the larval intestines were $5 \mu$, using a rotory microtome (Leitz 1512). The tissues were stained with Hematoxiline-eosine using the Entellan mounting medium and Hemacolor (Muñetón-Gómez et al., 2000). All the cuts were checked under a light microscope (maximum magnification 1000X) using immersion oil to evaluate the presence of monocytic cells that characterize the non-specific immune system in the larval intestines. The monocytic cells in both intestinal sections were evaluated.

The survival $(\mathrm{S})$ and growth $\left(\mathrm{G}_{\mathrm{s}}\right)$ data for the larvae in the experimental treatments were compared using analysis of varianza (ANOVA), prior to their transformation to the arc-sine of the square root (Sokal \& Rohlf, 1981). When the ANOVA showed significant differences, an a posteriori Tukey test was performed to detect differences between the treatment pairs. The effect of the application of $\beta \mathrm{G}$ MOS on the temporal increase in the standard length was evaluated with an analysis of covariance (ANCOVA). Before carrying out the ANOVA and ANCOVA, the normality of the data, the out-of-range data, and the homocedasticity of the variances were proven through the Barlett test, the Lilliefors test, and visual observation (Sokal \& Rohlf, 1981) using the computer software SYSTAT $8.0^{\circledR}$.

\section{RESULTS}

\section{Larval survival}

The effect of $\beta$ G MOS on the survival of $P$. adspersus larvae was dependent on the concentration of dilution applied to the rearing water. No significant differences were found between the survival percentages of six-day post-hatch individuals that received $5 \mathrm{mg} \cdot \mathrm{L}^{-1}$ $\beta \mathrm{G}$ MOS in the larval rearing water (Experiment $1)$ and the control group $\left(0 \mathrm{mg} \cdot \mathrm{L}^{-1} \beta \mathrm{G}\right.$ MOS; Fig. 1). However, survival decreased significantly $\left(F_{(3.8)}\right.$ $=9.018, \mathrm{p}<0.05$; Fig. 1) with the use of greater concentrations ( 10 and $\left.15 \mathrm{mg} \cdot \mathrm{L}^{-1}\right)$ of $\beta G$ MOS with respect to the control group and the other treatment. For the 15-day post-hatch larvae (Experiment 2), the application of $5 \mathrm{mg} \cdot \mathrm{L}^{-1}$ of $\beta \mathrm{G}$ MOS in the rearing water significantly improved $\left(\mathrm{F}_{(3.8)}=5.68, \mathrm{p}<\right.$ $0.05)$ the survival rates as compared with the control situation $\left(0 \mathrm{mg} \cdot \mathrm{L}^{-1} \beta \mathrm{G} \mathrm{MOS}\right)$ and the other treatments (Fig. 1). Concentrations of 10 and $15 \mathrm{mg} \cdot \mathrm{L}^{-1}$ of $\beta \mathrm{G}$ MOS significantly decreased $\left(\mathrm{F}_{(3.8)}=5.68, \mathrm{p}\right.$ $<0.05)$ the survival of the larvae with respect to the control situation (Fig. 1). Larval survival was also affected by the age of the larvae when the compound was applied. So, although a similar tendency was observed in both experiments, the application of $\beta \mathrm{G}$ MOS to the six-day post-hatch larvae resulted in $13 \%$ more survival than when applied to 15-day post-hatch larvae (Fig. 1). In this context, the partial increments in the survival percentage of the 6-day post-hatch larvae as compared with the 15 -day posthatch larvae were $12 \%\left(5 \mathrm{mg} \cdot \mathrm{L}^{-1}\right), 18 \%\left(10 \mathrm{mg} \cdot \mathrm{L}^{-1}\right)$, and $10 \%\left(15 \mathrm{mg} \cdot \mathrm{L}^{-1} \beta \mathrm{G}\right.$ MOS$)$. 


\section{Larval growth}

The standard length of both the larvae treated with $\beta G$ MOS and those in the control groups $\left(0 \mathrm{mg} \cdot \mathrm{L}^{-1}\right.$ $\beta G$ MOS) of both experiments showed a significant increase over time (Experiment 1: $\mathrm{F}_{(4.52)}=43.806$, $\mathrm{p}<0.05$; Experiment $\left.2: \mathrm{F}_{(4.52)}=133.283, \mathrm{p}<0.05\right)$. Nonetheless, the effect of the concentration of the $\beta G$ MOS concentration depends on the age of the larvae (6-day versus 15-day post-hatch). In the 6-day post-hatch larvae (Experiment 1), the increment in standard length during the time of the experiment was significantly greater in the individuals treated with $5 \mathrm{mg} \cdot \mathrm{L}^{-1} \beta \mathrm{G}$ MOS (approximately $10 \%$ larger) than in the other treatments; concentrations of 15 $\mathrm{mg} \cdot \mathrm{L}^{-1}$ of the compound significantly affected the standard length of the individuals, resulting in smaller final sizes $\left(\mathrm{F}_{(3.52)}=3.655, \mathrm{p}<0.05\right.$; Tukey test). In 15-day post-hatch larvae (10 days feeding rotifers; Experiment 2), the increment in the standard length showed a similar temporal tendency in all the treatments, including the control (Fig. 2).

The concentration of $\beta \mathrm{G}$ MOS applied to the rearing water affected the growth rates of the $P$. adspersus larvae. The growth rate of the 6-day posthatch larvae (Experiment 1 ) treated with $5 \mathrm{mg} \cdot \mathrm{L}^{-1} \beta \mathrm{G}$ MOS was significantly higher than the rate observed for the control larvae $\left(\mathrm{F}_{(3.8)}=91.040, \mathrm{p}<0.05\right)$ and the larvae treated with 10 and $15 \mathrm{mg} \cdot \mathrm{L}^{-1} \beta \mathrm{G}$ MOS (Fig. 3). The growth rate of the 15-day post-eclosion larvae (Experiment 2) treated with $5 \mathrm{mg} \cdot \mathrm{L}^{-1} \beta \mathrm{G}$ MOS was similar to the larvae maintained in the control condition $\left(\mathrm{F}_{(3.8)}=91.040, \mathrm{p}>0.05\right)$ and significantly higher $\left(\mathrm{F}_{(3.8)}=6.231, \mathrm{p}<0.05\right)$ than that observed for the larvae treated with 10 and $15 \mathrm{mg} \cdot \mathrm{L}^{-1} \beta \mathrm{G}$ MOS (Fig. 3). Although the larvae treated with $5 \mathrm{mg} \cdot \mathrm{L}^{-1}$ $\beta G$ MOS presented the greatest growth rates in both experiments, the compound was most effective for growth in the 6-day post-hatch larvae (Fig. 3).

\section{Histological analysis}

The histological analyses of the anterior and posterior intestines of the larvae stained with Hematoxiline-eosine and Hemacolor showed clearly differentiated monocytic cells, characterized by well-defined nuclei (Fig. 4). The temporal followup of the treatments through histological analyses showed a greater relative frequency of monocytes in the groups treated with $\beta$ G MOS on the tenth day of the experiment than in the normal or control group. Likewise, a high variability was detected between the histological cuts of the larval intestines given the same treatment, making it impossible to statistically quantify and evaluate in which $\beta \mathrm{G}$ MOS treatment the monocytes were more frequent. The presence of monocytic cell as a macrophage precursor is an evidence that complements the results of the effect of the $\beta$ G MOS on the survival and growth of $P$. adspersus the larvae in intense culture systems.

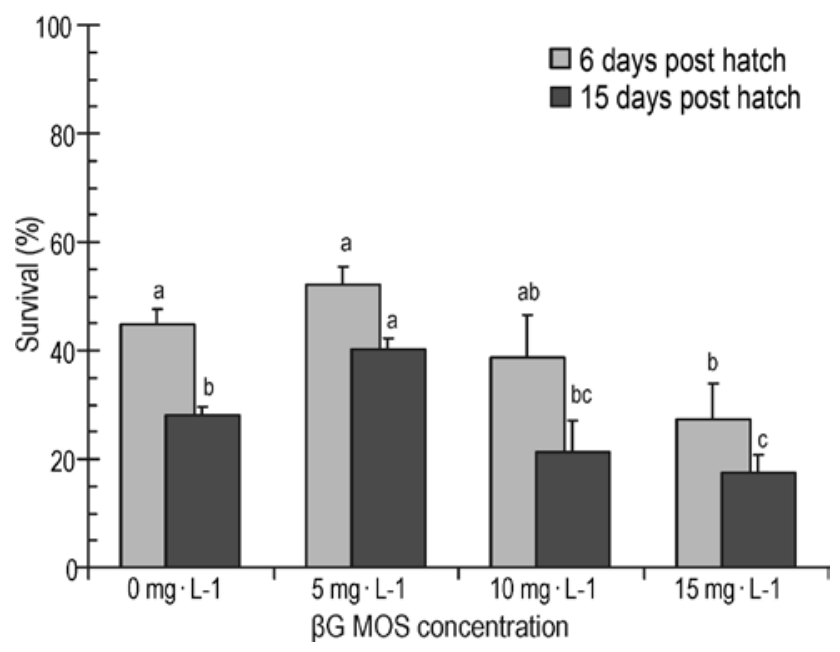

Figure 1. Survival (\%) of $P$. adspersus larvae of six day post hatch (Experiment $N^{\circ} 1$-clear bars) and fifteen days post hatch (Experiment $\mathrm{N}^{\mathbf{0}}$ 2-dark bars) treated with $\beta G$ MOS at different concentrations. The $0 \mathrm{mg} \cdot \mathrm{L}^{-1} \boldsymbol{\beta G} \mathrm{MOS}$ concentration corresponds to the control larval group. The letters indicate homogenous groups obtained from Tukey test $(\mathbf{p}<\mathbf{0 . 0 5})$. Mean \pm Standard deviation. 


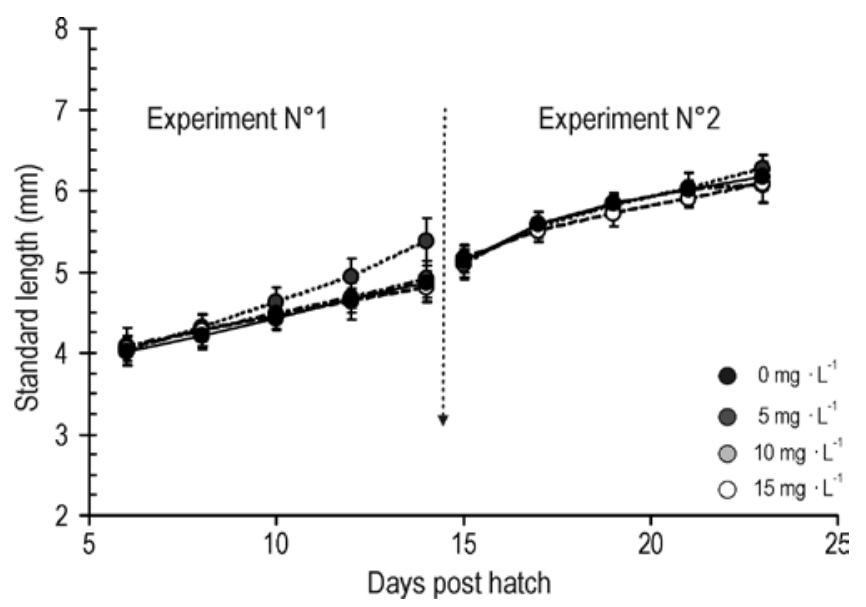

Figure 2. Standard length increment of $P$. adspersus larvae of six days post hatch (Experiment $\left.N^{\circ} 1\right)$ and fifteen days post hatch (Experiment $\mathrm{N}^{\circ}$ ) treated with $\beta G$ MOS at different concentrations. The $0 \mathrm{mg} \cdot \mathrm{L}^{-1} \beta G \mathrm{MOS}$ concentration corresponds to the control larval group. Mean \pm Standard deviation.

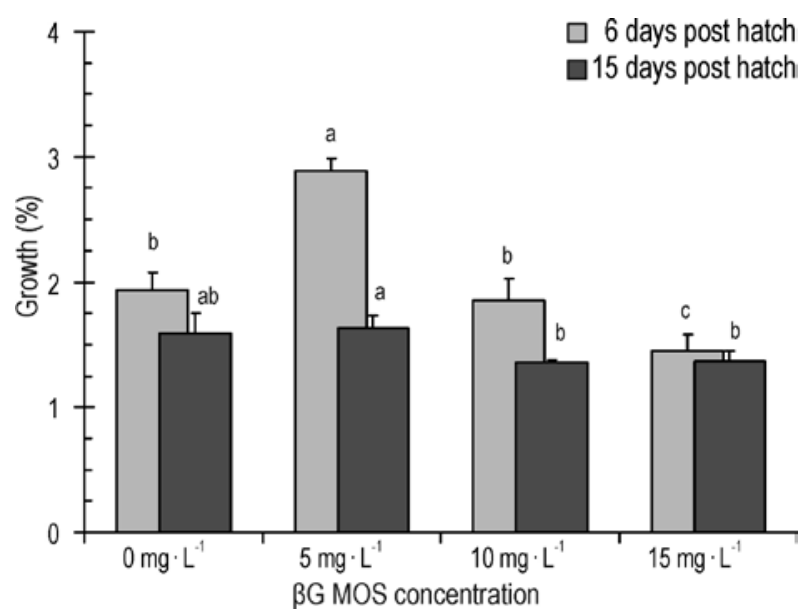

Figure 3. Growth (\%) of $P$. adspersus larvae of six day post hatch (Experiment $\mathbf{N}^{\mathbf{0} 1-c l e a r}$ bars) and fifteen days post hatch (Experiment $\mathrm{N}^{\mathbf{0}}$ 2-dark bars) treated with $\beta \mathrm{G}$ MOS at different concentrations. The $0 \mathrm{mg} \cdot \mathrm{L}^{-1} \boldsymbol{\beta G} \mathrm{MOS}$ concentration corresponds to the control larval group. The letters indicate homogenous groups obtained from Tukey test $(\mathbf{p}<\mathbf{0 . 0 5})$. Mean \pm Standard deviation.

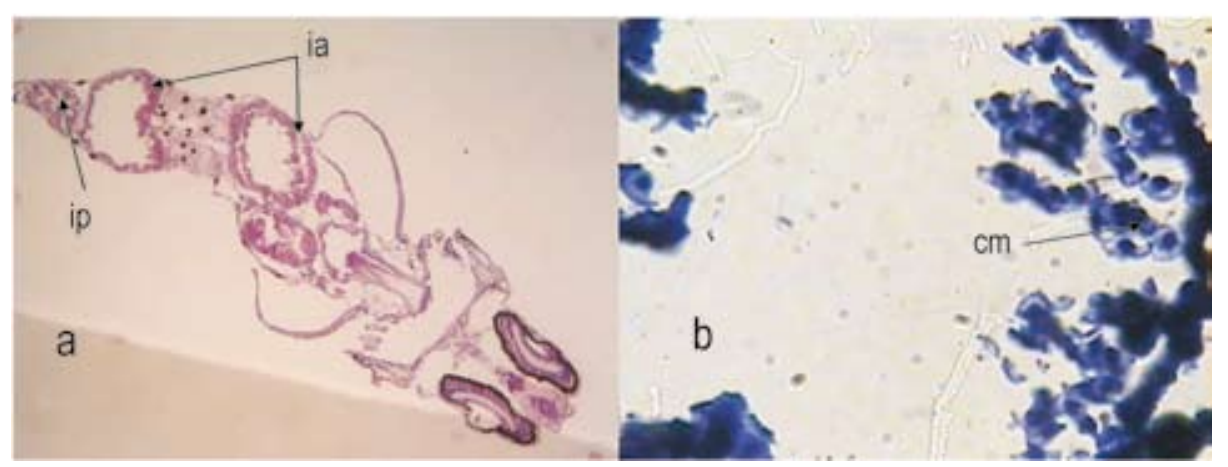

Figure 4. a) Histological slide of $P$. adspersus larvae of 23 days post hatch stain with Hematoxilin-Eosin (10x); there are observed anterior intestine (ia) and posterior intestine (ip). b) Histological slide of posterior intestine (1000x) stain with Hemacolor; are observed group of monocytic cells in intestinal tissue. 


\section{DISCUSSION}

Among the administration protocols of $\beta$-glucanbased compounds were successful in improving the health of larvae reared in captivity, oral administration was noteworthy. This administration protocol is useful for rearing $P$. adspersus larvae when is given during the first feeding stage with live prey depends on the concentration of $\beta$ G MOS applicated. Similar results, using the same protocol, have been obtained for Hippoglossus hippoglossus and Scophthalmus maximus larvae, as well as for other fish species raised in captivity (Dalmo et al., 2000; Bergh et al., 2001; Skjermo \& Bergh, 2004). In our study, the application of $5 \mathrm{mg} \cdot \mathrm{L}^{-1} \beta \mathrm{G}$ MOS significantly increased survival and growth of $P$. adspersus larvae, whereas concentrations of $15 \mathrm{mg} \cdot \mathrm{L}^{-1} \beta \mathrm{G}$ MOS suppressed these population parameters. An excess of prophylactic compounds applied to Sparus aurata suppressed the non-specific immune response and had negative consequences for the survival and development of the individuals (Mulero et al., 1998). This explanation could respond to the results found in this study, as an excess of this type of prophylactic compound could interfere in the optimal or posterior development of the larval immune systems (Bricknell \& Dalmo, 2005).

The age at which the $\beta \mathrm{G}$ MOS is applied also affects the farming of $P$. adspersus larvae. The application of $\beta \mathrm{G}$ MOS at the beginning of the first feeding (live prey) stage increases survival and growth as compared with the treatments given after ten days of feeding on live prey. This result challenges the expected results, that is that older $P$. adspersus larvae should have greater life expectancies (Silva, 2000, 2001). Some as yet unidentified compounds of maternal origins might provide innate protection against opportunistic bacteria. Eggs are rich in some non-specific defense compounds such as lectins and lysosomes (that probably come from the ovary) that differentiate macrophages early in the embryonic development (Ellis, 2001). Nevertheless, these compounds decrease with larval age (Browman et $a l ., 2003)$. Thus, the application of $\beta$ G MOS should complement and strengthen the immunity of the $P$. adspersus larvae that is transmitted by the mother during the early stages of development, mainly after the period in which the larvae have a yolk sac. However, this innate defense mechanism of the eggs and larvae seems to depend on the mother's state of health (Ellis, 2001; Browman et al., 2003).
The temporal increase in the standard length of the $P$. adspersus larvae in the experimental groups presented a similar tendency as that observed in prior studies (Silva \& Flores, 1989; Silva 2000, 2001). However, when compared with these studies, the larvae treated with $\beta \mathrm{G}$ MOS had higher growth rates, particularly when treated with $5 \mathrm{mg} \cdot \mathrm{L}^{-1} \beta \mathrm{G}$ MOS. Nevertheless, this result cannot be completely attributed to the effect of the $\beta G$ MOS application since these differences could be related to extrinsic factors such as temperature, light, and other environmental factors (Silva \& Flores, 1989; Downing \& Litvak, 1999; Silva 2000, 2001; Skjermo \& Bergh, 2004) that could have a synergic effect with the concentration of $\beta \mathrm{G}$ MOS applied to the rearing water.

In our experiment, the tissues of the intestinal epithelium revealed cells with circular, well-defined, mid-sized nuclei; these characteristics, according to the literature, define the monocytes (Esteban et al., 1994). The monocytes that are macrophage precursors are key cells in the non-specific defense system of the fish (Dalmo et al., 1997). Such cells may have one or several nuclei and are able to endocyte and to phagocyte foreign bodies that enter to the organism (1-10 $\mu \mathrm{m}$ in size) due to the presence of glycoprotein receptors in their plasmatic membrane that modify their means for secretions and marker substances (Esteban et al., 1994; Dalmo et al., 1997). When the macrophages are stimulated, they produce an intermediate reaction of oxygen, nitric oxides, enzymes, lysozymes, cytokines, and other marker molecules (Bricknell \& Dalmo, 2005). The high frequency of monocytes in the intestinal tissues and the greater growth and survival of the individuals treated with $\beta G$ MOS suggest a positive effect on the health of the $P$. adspersus larvae.

For $P$. adspersus individuals living in captivity, vibriosis is an opportunistic pathological process associated with situations of stress such as changes in the diet and/or increased temperature; it can be treated with wide-spectrum antimicrobial agents (Miranda \& Rojas, 1993, 1996). Further experiments with this type of opportunistic pathogenic strain and P. adspersus larvae previously treated with $\beta$ G MOS baths could complement our results, also considering the intrinsic variability of the responses of individuals from a single cohort.

This study is the first to indicate that the application of $\beta \mathrm{G}$ MOS $\left(5 \mathrm{mg} \cdot \mathrm{L}^{-1} \beta \mathrm{G}\right.$ MOS) diluted in the rearing water for five days significantly increases the percentage of survival as compared with the control 
situation, or as compared to other previous studies carried out with $P$. adspersus larvae (Silva \& Flores, 1989; Silva, 2000, 2001). The degree of protection obtained by administering this compound is probably related to the stimulation of the non-specific components of the immune system that have antibacterial activity, as shown by the presence of macrophage precursor cells. Other studies carried out on flat fish (e.g., Hippoglossus hippoglossus, Scophthalmus maximus, Paralichthys olivaceus) have suggested that the administration of compounds containing $\beta$-glucans improves resistance against opportunistic bacteria (Robertsen et al., 1994; Dehasque et al., 1997; Strand \& Dalmo, 1997; Sakai, 1999; Dalmo et al., 1997, 2000; Bergh et al., 2001; Bricknell \& Dalmo, 2005). It is in this context that $\beta \mathrm{G}$ MOS, or other products acting as prophylactic compounds, should be considered as a tools for prevention when planning and developing management schemes for the intensive production of $P$. adspersus juveniles, particularly during the first feeding (live prey) stage of the larvae.

\section{ACKNOWLEDGEMENTS}

The authors would like to thank the Laboratorio de Cultivo Peces of the Facultad de Ciencias del Mar, Universidad Católica del Norte, for providing the infrastructure for carrying out the present research. They are also grateful for the disposition of the Master's candidate Marcia Oliva and the team that makes up the Unidad de Producción of the Facultad de Ciencias del Mar. They further thank Mr. Alexis Ruiz (DESPRO S.A.) for providing the compound used in the experiments. Finally, the authors appreciate the insightful comments and suggestions made by the anonymous reviewers that were helpful in elaborating the final version of this study.

\section{REFERENCES}

Anderson, D. 1992. Immunostimulants, adjuvants and vaccine carriers in fish: application to aquaculture. Ann. Rev. Fish Dis., 2: 281-307.

Angeles, B. \& J. Mendo. 2005. Crecimiento, fecundidad y diferenciación sexual del lenguado Paralichthys adspersus (Steindachner) de la costa central del Perú. Ecol. Apl., 4: 105-112.

Bergh, Ø., F. Nilsen \& O.B. Samuelsen. 2001. Diseases, prophylaxis and treatment of the Atlantic halibut Hippoglossus hippoglossus: a review. Dis. Aquat. Org., 48: 57-74.

Bisbal, G. \& D. Bengtson. 1995. Effects of delayed feeding on survival and growth of summer flounder Paralichthys dentatus larvae. Mar. Ecol. Prog. Ser., 121: 301-306.

Bricknell, I. \& R.A. Dalmo. 2005. The use of immunostimulants in fish larval aquaculture. Fish Shellfish Immunol., 19: 457-472.

Browman, H., J.F. St-Pierre, A.B. Skiftesvik \& R.G. Racca. 2003. Behaviour of Atlantic cod (Godus morhua) larvae: an attempt to link maternal condition with larval quality. In: J. Browman \& A. Skiftesvik (ed.). The Big Fish Bang Proceedings of the $26^{\text {th }}$ Annual Larval Fish Conference. Bergen, Norway, pp. 72-94.

Cousin, J.C.B., G. Balouet \& F. Baudin-Laurencin. 1986. Alteration histoligiques observées chez des larves de turbot (Scophthalmus maximus L) en élèvage intensive. Aquaculture, 52: 173-189.

Dalmo, R.A., K. Ingebrigtsen \& J. Bøgwald. 1997. Non-specific defence mechanisms in fish, with particular reference to the reticuloendothelial system (RES). J. Fish Dis., 20: 241-273.

Dalmo, R., A. Kjerstad, S. Arnesen, P. Tobias \& J. Bøgwald. 2000. Bath exposure of Atlantic halibut (Hippoglossus hippoglossus) yolk sac larvae to bacterial lipopolysaccharide: absorption and distribution of the LPS and effect on fish survival. Fish Shellfish Immunol., 10: 107-128.

Dehasque, M., J. van Assche \& B. Deberse. 1997. Evaluación de los efectos de la administración oral de inmunoestimulantes en las enfermedades de especies para acuicultura. [http://w3.dsi.uanl. $\mathrm{mx} /$ publicaciones/maricultura/acuicolaIII/pdfs/6. pdf], Revised: 10 June 2006

Downing, G. \& M.K. Litvak. 1999. The effect of photoperiod, tank colour and light intensity on growth of larval haddock. Aquacult. Int., 7: 369-382.

Ellis E. A. 2001. Innate host defence mechanism of fish against viruses and bacteria. Dev. Comp. Immunol., 25: 827-839.

Esteban, M.A., J. Muñoz, A. López-Ruiz, V. Mulero \& J. Meseguer. 1994. Respuesta inespecífica en peces frente a las infecciones bacterianas. Inflamación, fagocitosis. In: S. Zamora, B. Aguilleiro \& M.P. García-Hernández (eds.). Aulas del Mar. Universidad de Murcia, Murcia, pp. 235-244.

Kumari, J. \& P.K. Sahoo. 2006. Dietary $\beta-1,3$ glucan potentoes innate immunity and disease resistance of Asian catfish, Clarias batrachus (L.). J. Fish Dis., 29: 95-101. 
Kuronuma, K. \& K. Fukusho. 1984. Rearing of marine fish larvae in Japan. Otawa, Ont. IDRC, 190 pp.

Luizi, F.S., B. Gara, R. Shield \& N. Bromage. 1999. Further description of the development of the digestive organs in Atlantic halibut (Hippoglossus hippoglossus) larvae, with notes on differential absorption of copepod and Artemia prey. Aquaculture, 175: 101-116.

Miranda, C.D. \& R. Rojas. 1993. Prevalencia de patologías oportunistas en el cultivo experimental del lenguado Paralichthys adspersus. Anal. Microbiol., 1: 51-54.

Miranda, C.D. \& R. Rojas. 1996. Vibriosis en el lenguado Paralichthys adspersus (Steindachner 1867) en cautiverio. Rev. Biol. Mar., 31(1): 1-9.

Muñetón-Gómez, M. del S., M. Villarejo-Fuerte \& G. García-Melgar. 2000. Manual de técnicas histológicas aplicadas a organismos marinos. Universidad Autónoma de Baja California del Sur. Publicación del Centro Interdisciplinario de Ciencias Marinas (CICIMAR), $81 \mathrm{pp}$.

Mulero, V., M. Esteban, J. Muñoz \& J. Meseguer. 1998. Dietary intake of levamisole enhances the immune response and disease resistance of marine teleost gilthead seabream (Sparus aurata L.). Fish Shellfish Immunol., 8: 49-62.

Pryor, G., B. Royes, F. Chapman \& R. Miles. 2003. Mannanooligosaccharides in Fish nutrition: effects of dietary supplementation on growth an gastrointestinal villi structure in Gulf of Mexico Sturgeon. N. Am. J. Aquacult., 65: 106-111.

Raa, J. 2000. The use of immune-stimulants in fish and shellfish feeds. [http://w3.dsi.uanl.mx/publicaciones/maricultura/acuiculturaV/raa.pdf]. Revised: 3 January 2006.

Ribeiro, L., C. Sarasquete, \& M.T. Dinis. 1999. Histological and histochemical development of the digestive system of Solea senegalensis (Kaup, 1858) larvae. Aquaculture, 171: 293-308.

Robertsen, B., R.E. Engstad \& J.B. Jorgensen. 1994. B-Glucans as immunostimulants. Modulators of fish immune responses. In: J. Stolen \& T.C. Fletcher. Fair Haven, SOS., 1: 83-99.

Rottmann, R.W., R. Francis-Floyed \& R. Durborow. 1992. The role of stress in fish disease. Publication No. 474, Southern Regional Aquaculture Center, 3 pp.

Sakai, M. 1999. Current research status of fish immunostimulants. Aquaculture, 172: 63-92.

Silva, A. 2000. Bases biológico-técnicas para el desar- rollo del cultivo artificial del lenguado chileno (género Paralichthys). Tesis de Doctorado en Ciencias Biológicas. Universidad de Barcelona. Barcelona, $122 \mathrm{pp}$.

Silva, A. 2001. Advances in the culture research of small-eye flounder, Paralichthys microps, and Chilean flounder, P. adspersus, in Chile. J. Appl. Aquacult., 11: 147-164.

Silva, A. \& H. Flores. 1989. Consideraciones sobre el desarrollo y crecimiento larval del lenguado (Paralichthys adspersus, Steinadchner, 1987) cultivado en laboratorio. Rev. Pacífico Sur, Número Especial: 629-634.

Silva, A. \& F. Castelló. 2005. Técnicas de producción de huevos y larvas de peces. In: A. Silva (ed.). Cultivo de peces marinos. Universidad Católica del Norte, Coquimbo, pp. 159-184.

Silva, A. \& A. Vélez. 2005. Cultivo de alimento vivo para larvas de peces marinos In: A. Silva (ed.). Cultivo de peces marinos. Universidad Católica del Norte, Coquimbo, pp. 61-100.

Skjermo, J. \& O. Vadstein. 1999. Techniques for microbial control in the intensive rearing of marine larvae. Aquaculture, 177: 333-343.

Skjermo, J. \& Ø. Bergh. 2004. High-M alginate immunostimulation of Atlantic halibut (Hippoglossus hippoglossus L.) larvae using Artemia for delivery, increases resistance against vibriosis. Aquaculture, 238: 107-113.

Sokal, R.R. \& F.J. Rohlf. 1981. Biometry: principles and practice of statistical in biological research. W.H. Freeman \& Company, San Francisco, 776 pp.

Strand, H. \& R. Dalmo. 1997. Absorption of immunomodulating $(\beta(1,3)$-D-glucan $)$ in yolk sac larvae of Atlantic halibut, Hippoglossus hippoglossus (L.). J. Fish Dis., 20: 41-49.

Servicio Nacional de Pesca (SERNAPESCA). 2005. Diagnóstico ambiental de la acuicultura chilena en función de los estándares establecidos en el Reglamento Ambiental para la Acuicultura (RAMA). Departamento de Administración Pesquera, 44 pp.

Tytler, P. \& J.H. Blaxter. 1988. The effects of external salinity on the drinking rates of the larvae of herring, plaice and cod. J. Exp. Biol., 138: 1-15.

Vadstein, O. 1997. The use of immunostimulation in marine larviculture: possibilities and challenges. Aquaculture, 155: 401-417.

Jin, Z. \& L. Xiao-ling. 2004. The use of peptidolglycan as an immune stimulant for turbot (Scophthalmus maximus). J. Fish Soc. Taiwan, 31: 155-158. 